\title{
ANALISIS STRATEGI HUMAS PDAM KOTA TERNATE DALAM PENANGANAN KELUHAN DAN KOMPLAIN WARGA KECAMATAN KOTA TERNATE UTARA DAN KOTA TERNATE TENGAH TERHADAP DAMPAK EKSPLOITASI SUMBER MATA AIR AKE GAALE
}

\author{
Mutia Dewi \\ Dosen Program Studi Ilmu Komunikasi FPSB UII \\ mutiaawel@gmail.com \\ Laily Wahyuni Djalaluddin \\ Alumnus Program Studi Ilmu Komunikasi FPSB UII \\ lailydj6692@gmail.com
}

\begin{abstract}
Based on the results of research, Public Relations of water supply company Ternate city in complain handling Ake Gaale water source, they perform of internal an external function. Public Relations of water supply company Ternate city excecutes four important steps started fact finding and defining the problem, planning and programming, action and communication, and evaluation. In the evaluation step, Public Relation of water supply company Ternate city found that each of the programs was not effectively done. Alternative step taken by Public relation was engaging the Government of Ternate to be involved in the follow-up meeting about problems at Ake Gaale water source, as well as the presence by Government of Ternate also intended to be a mediator in the mediation process between water supply company Ternate city and residents of Sangaji that failed to build their communication each other.
\end{abstract}

Keywords: Crisis, Public Relations, Ternate City

\begin{abstract}
Abstrak
Berdasarkan hasil penelitian, aktivitas Humas Perusahaan Daerah Air Minum (PDAM) Kota Ternate dalam penanganan keluhan dan komplain terkait permasalahan sumber mata air Ake Gaale, menjalankan peran dan fungsinya secara internal dan eksternal. Dalam prosesnya, Humas PDAM Kota Ternate menjalankan empat langkah penting yang di awali dari pengumpulan fakta dan mendefinisikan masalah, perencanaan dan program, aksi dan komunikasi, serta evaluasi. Pada tahap evaluasi, Humas PDAM Kota Ternate menemukan fakta bahwa setiap program yang dijalankan tidak berjalan efektif. Langkah alternatif yang diambil Humas PDAM Kota Ternate adalah mengajak Pemerintah Kota Ternate untuk terlibat dalam rapat tindak lanjut permasalahan sumber mata air Ake Gaale, serta kehadiran Pemerintah Kota Ternate juga diperuntukkan menjadi mediator dalam proses mediasi antara PDAM Kota Ternate dan warga Kelurahan Sangaji yang dianggap gagal dalam membangun komunikasi bersama.
\end{abstract}

Kata Kunci: Krisis, Humas, Kota Ternate. 


\section{PENDAHULUAN}

PDAM Kota Ternate merupakan satusatunya perusahaan yang menyediakan jasa pendistribusian air bersih kepada masyarakat Kota Ternate. Namun seiring berjalannya waktu, PDAM Kota Ternate menuai banyak kritik dari masyarakat tentang kinerjanya. Adanya tuduhan masyarakat terhadap PDAM Kota Ternate yang melakukan eksploitasi berlebihan pada sumber mata air Ake Gaale, menyebabkan terjadinya krisis kepercayaan oleh masyarakat setempat. Kondisi ini juga diperburuk dengan keadaan sumber mata air Ake Gaale yang mulai mengering dan rusak yang berdampak pada krisis pelayanan air bersih terhadap warga di Kecamatan Kota Ternate Utara dan Kota Ternate Tengah. Dengan demikian terjadi keluhan dan komplain dari warga tersebut.

Persoalan ini berawal Eksploitasi yang berlebihan oleh PDAM Kota Ternate. Puncaknya terjadi pada saat pembangunan sumur raksasa yang berukuran sekitar $20 \mathrm{X}$ 15 meter serta tembok diatas jalur mata air Ake Gaale sehingga membuat air berhenti mengalir. Ake Gaale yang kosong kemudian dimasuki oleh air laut yang jaraknya memang dekat dengan mata air tersebut. Akibat dari perembesan air laut (intrusi) ini, sumur-sumur warga yang berada disekitar sumber mata air tersebut menjadi payau (Malut Post, 5 Juni 2015).

Salah satu temuan Kepala Pelaksanaan Jaringan Pemanfaatan Air Maluku Utara, Rizali Sahan, menjelaskan bahwa Ancaman bencana kekeringan dan krisis air bersih di lingkungan Ake Gaale Kelurahan Sangaji, Ternate Utara nampaknya harus mendapat perhatian khusus, jika tidak dituntaskan maka masyarakat akan kesulitan menikmati air bersih (Berita Satu, 20April 2015).

Oleh karena adanya krisis kepercayaan dan krisis pelayanan air bersih yang dialami PDAM Kota Ternate menyebabkan terjadinya keluhan dan komplain yang berkepanjangan dari warga yang tentunya berpengaruh terhadap citra dari PDAM Kota Ternate itu sendiri. Krisis tersebutdiawali dari keluhandan komplain yang di sampaikan melalui media cetak lokal Malut Post, bahkan komplain yang dilakukan oleh warga Kelurahan Sangaji Utara pernah diliput oleh salah satu media televisi nasional Metro TV pada tahun 2015.

Kondisi ini mengindikasikan munculnya rasa ketidakpuasan warga terhadap kinerja PDAM Kota Ternate. Sebagai perusahaan yang citra dan kinerjanya selalu dinilai oleh publik luar, PDAM Kota Ternate tentu memiliki bagian hubungan masyarakat (Humas) yang bertugas untuk menjembatani atau membangun komunikasi dengan masyarakat luar sebagai publik, yang pada akhirnya dapat menentukan sukses atau tidaknya tujuan dan citra yang hendak dicapai oleh PDAM Kota Ternate. Namun dengan adanya keluhan dan komplain yang secara terus menerus ini mengindikasikan kurangnya efektifitas Humas PDAM Kota Ternate sendiri dalam menerapkan strategi penanganan keluhan dan komplain dari warga tersebut.

Dengan demikian muncul beragam polemik terkait peranan Humas PDAM Kota Ternate dari berbagai macam kalangan masyarakat, khususnya peneliti. Polemik yang berkembang ini mengharuskan adanya suatu pendekatan ilmiah untuk menjawab seperti apa strategi Humas PDAM Kota Ternate dalam menangani keluhan dan komplain warga. Lebih lanjut, belum adanya penelitian yang mengkaji tentang masalah ini, menyebabkan kurangnya informasi ilmiah tentang Humas PDAM Kota Ternate.

Berdasarkan uraian latar belakang diatas. maka peneliti tertarik melakukan penelitian dengan judul "Analisis Strategi Humas PDAM Kota Ternate Dalam Penanganan Keluhan dan Komplain Warga Kecamatan Kota Ternate Utara dan Kota Ternate Tengah Terhadap Dampak Eksploitasi Sumber Mata Air Ake Gaale”.

Keluhan dan komplain yang tidak mereda menjadi polemik di mata masyarakat, khususnya peneliti terkait peran dan fungsi dari salah satu bagian dalam struktur PDAM Kota Ternate yang bertanggung jawab dalam menjalin hubungan dengan masyarakat yakni Humas. Oleh karena itu, perlu dilakukan suatu pendekatan ilmiah berupa penelitian untuk mengetahui bagaimana peran dan 
fungsi Humas PDAM Kota Ternate dalam penanganan keluhan dan komplain warga.

\section{METODE}

Metodeyang digunakan dalam penelitian ini adalah metode kualitatif, berupa penelitian deskriptif induktif eksploratori, dengan menganalisis dan mengeksplorasi secara mendalam fenomena yang menjadi minat penelitian ini terutama dalam bidang kehumasan. Penelitian kualitatif sendiri merupakan penelitian yang bermaksud untuk memahami fenomena tentang apa yang dialami oleh subjek penelitian, dengan cara deskriptif dalam bentuk kata-kata dan bahasa, pada suatu konteks khusus yang alamiah dan dengan memanfaatkan berbagai metode ilmiah (Moleong, 2005: 6).

Waktu pelaksanaan penelitian dilakukan secara bertahap yang diawali dari tahap pengumpulan informasi dan observasi lokasi penelitian (10-21 Juli 2015), analisis induktif melalui studi pustaka dan wawancara dengan narasumber (15 Desember 2015-15 Januari 2016), sertatahappenyusunanlaporanakhirpenelitian (20 Desember 2015- 26 Mei 2016).

Lokasi penelitian bertempat di kantor PDAM Kota Ternate, Kecamatan Kota Ternate Utara yang meliputi Kelurahan Sangaji, Akehuda, Tubo, Soa Sio, dan Kasturian, serta Kecamatan Kota Ternate Tengah yang meliputi Kampung Makasar Timur dan Kampung Makasar Barat.

Pemilihan narasumber ditekankan pada bagian terkait yakni Humas dan Hubungan Langganan PDAM Kota Ternate, serta warga dari Kelurahan yang berada di Kecamatan Kota Ternate Utara dan Kota Ternate Tengah. Narasumber penelitian terdiri dari:

a) Bapak Mirza Hi. Hasyim selaku Kasub Seksi Humas PDAM Kota Ternate

b) Ibu Hj. Asma M. Don selaku Kasi Hubungan Langganan PDAM Kota Ternate

c) Bapak Alwan M. Arief selaku aktivis Save Ake Gaale dan warga Kelurahan Sangaji Kecamatan Kota Ternate Utara.

d) Para warga (13 Responden) dari Kelurahan yang berada di Kecamatan Kota Ternate Utara dan Kota Ternate Tengah selaku pelanggan PDAM Kota Ternate.

\section{Kerangka Pemikiran}

\section{Humas Pemerintahan}

Menurut Effendy (2006: 23),hubungan masyarakat (Humas) adalah komunikasi dua arah antara organisasi dengan publik secara timbal balik dalam rangka mendukung fungsi dan tujuan manajemen dengan meningkatkan pembinaan kerja sama dan pemenuhan kepentingan bersama. Lebih lanjut dijelaskan Danny Grinsworld dalam Kasali (2000:7), Humas adalah fungsi manajemen yang melakukan evaluasi terhadap sikap dua publik, mengidentifikasikan kebijakan dan prosedur seseorang atausebuah perusahaan terhadap publiknya, menyusun rencana serta menjalankan program-program komunikasi untuk memperoleh pemahaman dan penerimaan publik.

Lebih lanjut Cutlip, Center, dan Broom(2006: 466), menjelaskan hubungan masyarakat dalam lembaga pemerintahan secara umum bertujuan untuk memberi informasi konstituen tentang aktivitas agen pemerintah, memastikan kerjasama aktif dalam program pemerintah, mendorong warga mendukung kebijakan dalam program pemerintahyangsudahditetapkan, mengelola informasi internal, serta memfasilitasi hubungan media.

Merujuk pada defenisi yang diuraikan diatas, makadapatterlihat denganjelas bahwa humas pemerintah lebih menekankan pada aktivitas menyebarkan informasi ketimbang aktivitas komersial seperti pada perusahaan bisnis. Ini berarti humas lebih berperan sebagai kepanjangan tangan pemerintah kepada warganya. Selanjutnya Black dalam (Effendy, 2006: 37-38) juga menjelaskan bahwa pembagian tugas humas pemerintah daerah maupun pusat memiliki perbedaan. Jika pada humas pemerintah pusat lebih menekankan pada peran untuk mendidik masyarakat agar paham tentang undangundang maupun peraturan yang dibuat oleh pemerintah pusat dalam hal ini negara, 
maka humas pemerintah daerah lebih fokus pada memberikan informasi kebijakan daerah sekaligus memberi kesempatan pada warga untuk menyatakan pandangannya atas proyek baru yang akan dilakukan oleh pemerintah daerah.

Lebih lanjut Cutlip menjelaskan bahwa peranan Humas dalam suatu organisasi dapat dibagi menjadi empat kategori, yaitu penasihat ahli (expert presciber), fasilitator komunikasi (communication fasilitator), fasilitator proses pemecahan masalah (problem solving process fasilitator), serta teknisi komunikasi (communication technician). Dari pembagian peran tersebut terlihat bahwa Humas dalam sebuah organisasi memiliki kedudukan pada ruang lingkup internal dan eksternal organisasi.

Adapun langkah-langkah konkrit bagi humas dalam menjalankan tugasnya sebagai berikut:

1) Mendefinisikan Masalah. Seorang Humas perlu melibatkan diri dalam penelitian dan pengumpulan fakta. Selain itu Humas perlu memantau dan membaca terus pengertian, opini, sikap, dan perilaku mereka yang berkepentingan dan terpengaruh oleh sikap dan tindakan perusahaan. Tahap ini merupakan penerapan atau fungsi intelejen perusahaan. Adapun langkah yang dilakukan oleh seorang Humas harus setiap saat secara kontinu bukan hanya pada saat krisis terjadi.

2) Rencana dan Program. Seorang Humas sudah menemukan penyebab timbulnya permasalahan dan sudah siap dengan langkah-langkah pemecahan atau pencegahan. Langkah-langkah yang harus dirumuskan dalam bentuk rencana dan program, termasuk anggarannya. Pada tahap ini penting bagi Humas mendapatkan dukungan penuh dari pimpinan puncak perusahaan karena besar kemungkinan langkah yang diambil akan sangat strategis dan melibatkan keikutsertaan banyak bagian.

3) Aksi dan Komunikasi. Tahap pelaksanaan atau kegiatan dilakukan sesuai dengan fakta dan data yang telah dirumuskan dalam bentuk perencanaan. Pada tahap ini, aksi dan komunikasi harus dikaitkan dengan objective dan goals yang spesifik.

4) Evaluasi. Proses Humas selalu dimulai dari mengumpulkan fakta dan diakhiri pula dengan pengumpulan fakta. Untuk mengetahui prosesnya sudah selesai atau belum, seorang Humas perlu melakukan evaluasi atas langkah-langkah yang telah diambil. Maka, tahap ini akan melibatkan pengukuran atas hasil tindakan di masa lalu. Penyesuaian dapat dibuat dalam program yang sama, atau setelah suatu masa berakhir. (Kasali, 2000: 84-85)

\section{Humas dalam Manajemen Krisis: Langkah Awal Strategi Komunikasi}

Salah satu penyebab munculnya krisis adalah ketidaksigapan organisasi dalam merespon perubahan-perubahan yang terjadi di lingkungannya. Akibatnya krisis tersebut mampu mempengaruhi citra sebuah organisasi. Begitupun halnya dengan pemerintah daerah. Persoalan yang dibiarkan berlarut tanpa ada nya respon yang cepat akan berpotensi menimbulkan konflik dengan warga di daerah.

Defenisi krisis yang diberikan oleh Burnet dalam (Kriyantono, 2015: 198) menyebutkan bahwa krisis merupakan peristiwa yang berubah-ubah dan menjadi lebih serius serta membahayakan apabila telah mendapatkan rangsangan investigasi oleh media massa yang berakibat pada opini publik yang negatif.

Jadi, jika persoalan tersebut telah masuk pada ranah pemberitaan media massa, maka organisasi berada pada tahapan krisis yang serius. Disinilah peran Humas sebagai aktivitas fungsi dari teknisi komunikasi. Sebuah krisis bisa saja terjadi karena aktivitas fungsi manajemen komunikasi yang tidak baik sehingga menyebabkan terjadinya kekurangan dan ketidakpastian informasi.

Oleh karena itu humas bertanggung jawab membantu mengatasi krisis dengan cara menjamin bahwa publik dilayani dengan baik oleh organisasi. Humas berperan untuk 
menyarankanmanajemenuntukmenerapkan strategi komunikasi yang memungkinkan organisasi beradaptasi dengan situasi lingkungannya (Kriyantono,2015:244).

Strategi komunikasi merupakan penentu berhasil tidaknya kegiatan komunikasi secara efektif. Dengan demikian, strategi komunikasi, baik secara makro (planned multi-media strategi) maupun secara mikro (single communication medium strategi) mempunyai fungsi ganda (Effendy, 2000: 300),

a) Menyebarluaskan pesan komunikasi yang bersifat informatif, persuasif dan instruktif secara sistematik kepada sasaran untuk memperoleh hasil optimal

b) Menjembatani “cultural gap" akibat kemudahan diperolehnya dan kemudahan dioperasionalkannya media massa yang begitu ampuh yang jika dibiarkan akan merusak nilai-nilai budaya.

Dalam prosesnya, kegiatan komunikasi Humas tidak terlepas dari komunikasi langsung dan tidak langsung. Komunikasi langsung Humas terjadi secara tatap muka, sedangkan komunikasi tidak langsung biasanya menggunakan media perantara. Secara umum, komunikasi langsung dikenal dengan istilah komunikasi interpersonal. Sementara komunikasi melalui media, biasanya dikenal dengan komunikasi massa.

\section{HASIL DAN PEMBAHASAN}

\section{Manajemen Humas PDAM Kota Ternate}

Dalam menangani komplain warga, Humas PDAM Kota Ternate telah melakukan setidaknya empat proses manajemen pokok, sebagai berikut:

1. Pengumpulan Fakta dan Mendefinisikan Masalah

Komplain warga tentang masalah sumber mata air Ake Gaale ini pertama kali di terimaHumas PDAM Kota Ternate dari bagian Hubungan Langganan PDAM Kota Ternate. Pada proses penyampaian komplain, warga Kelurahan Sangaji datang dan menyampaikan langsung terkait masalah kualitas air sumur pribadi mereka yang bersumber dari mata air Ake Gaale menjadi asin. Selain itu, komplain tentang masalah kualitas air asin juga disampaikan oleh Kelurahan-Kelurahan lain dari Kecamatan Kota Ternate Utara dan Kota Ternate Tengah. Humas PDAM Kota Ternate sendiri memperoleh informasi tersebut melalui media yang telah disediakan sebelumnya yakni SMS Gateway dan kotak saran. Berikut Gambar media yang digunakan untuk penyampaian keluhan maupun komplain pelanggan di kantor PDAM Kota Ternate.

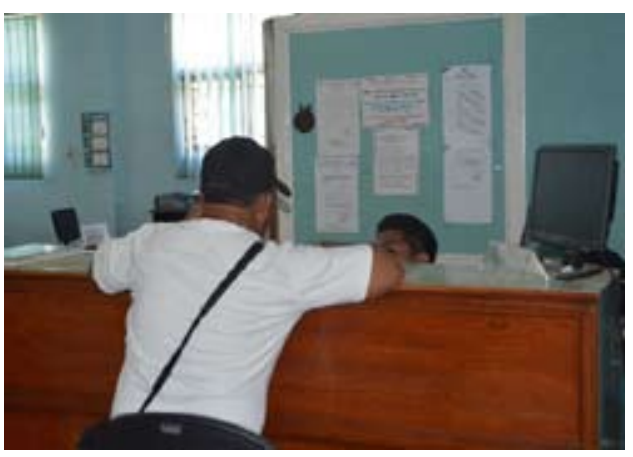

(1a). Menyampaikan Langsung

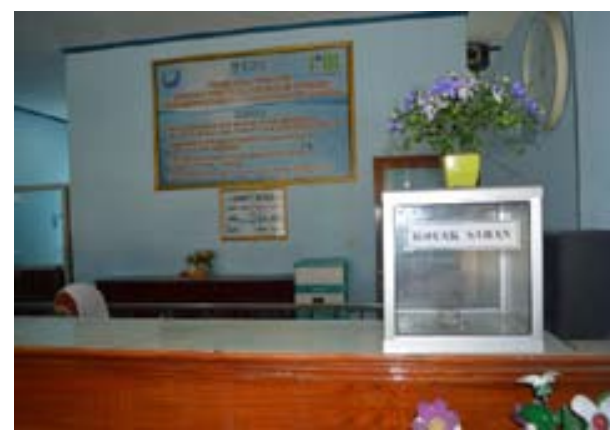

(1b). Kotak Saran

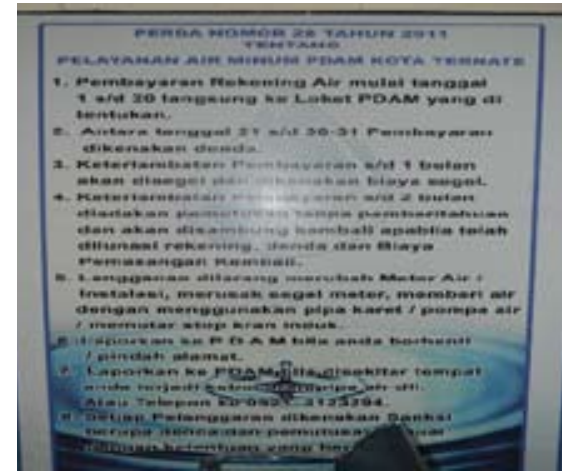

(1c). SMS Gateway

Gambar 1. Media Penyampaian Keluhan dan Komplain di PDAM Kota Ternate 
Humas PDAM Kota Ternate bertindak cepat dengan melibatkan Bagian Laboratorium PDAM Kota Ternate dan Dinas Kesehatan Kota Ternate untuk rutin melakukan pemeriksaan sampel air secara menyeluruh. Sampel air yang diambil, diuji di Laboratorium Manado. Hasil analisis sampel air menunjukkan bahwa kandungan zat terlarut TDS sudah melampaui ambang batas (PERMENKES 2010).

Pemeriksaan sampel air yang bersumber dari mata air Ake Gaale rutin dilakukan dengan tujuan mengetahui kondisi kualitas dan debit air di sumber mata air tersebut. Hasil dari pemeriksaan dapat disimpulkan bahwa debit air berkurang drastis dan kualitas air menjadi asin. Namun dengan adanya pengurangan produksi air, terjadi penurunan zat terlarut TDS yang terkandung dalam air.

Selanjutnya Humas PDAM Kota Ternate menganalisa opini yang berkembang di kalangan warga. Hasilnya, PDAM Kota Ternate dianggap sebagai pihak yang menyebabkan permasalahan sumber mata air Ake Gaale. Bersamaan dengan itu, warga menuntut kompensasi dari PDAM Kota Ternate berupa pemasangan gratis meter air dan dibebaskaniuran per bulannya untuk seluruh warga Kelurahan Sangaji. Selain itu, Humas PDAM Kota Ternate juga menemukan fakta bahwa terjadi dampak psikolog dan ekonomi yang cukup mempengaruhi kehidupan sehari-hari warga.

\section{Rencana dan Program}

Kasub Seksi Humas PDAM Kota Ternate menjelaskan bahwa PDAM Kota Ternate sepakat pada perumusan rencana dan program jangka pendek, diantaranya:

a. Pengurangan produksi air yang bersumber dari mata air Ake Gaale untuk mengantisipasi masalah krisis kualitas dan debit air di mata air tersebut. Rencana dan program ini dirumuskan dengan dasar bahwa terjadi penurunan zat terlarut TDS di sumber mata air Ake Gaale apabila produksi air dikurangi.

b. Pemasangan gratis air PDAM di rumah warga Kelurahan Sangaji
Kecamatan Kota Ternate Utara yang sebelumnya hanya menggunakan sumur pribadi yang bersumber dari mata air Ake Gaale, serta dibebaskan iuran per bulannya. Rencana dan program ini dirumuskan dengan dasar bahwa terjadi tuntutan dari warga untuk meminta kompensasi dari PDAM Kota Ternate. Selain itu, perumusan rencana dan program ini juga bertujuan untuk mengurangi dampak ekonomi dan psikolog yang di alami warga Kelurahan Sangaji Kota Ternate Utara.

c. Kelurahan-Kelurahan di Kecamatan Kota Ternate Tengah yang letaknya dianggap strategis, dilakukan perubahan jaringan air yang awalnya bersumber dari mata air Ake Gaale, dipindahkan ke sumber mata air alternatif yang berada di Kecamatan Kota Ternate Selatan atau Reservoir milik PDAM Kota Ternate terdekat. Rencana dan program ini dirumuskan dengan tujuan meminimalisir jumlah wilayah pelayanan PDAM KotaTernate yang mengalami krisis air bersih.

3. Aksi dan Komunikasi

Pada tahap realisasi program, Bagian Produksi PDAM Kota Ternate bertugas mengontrol kapasitas produksi air yang bersumber dari mata air Ake Gaale. Program ini dapat dikatakan cukup berhasil dikarenakan untuk sementara waktu dapat menyelesaikan masalah distribusi air yang terasa asin.

Selanjutnya, terkait dengan tuntutan warga Kelurahan Sangaji agar dipasangkan air PDAM secara gratis dan dibebaskan iuran per bulannya, PDAM Kota Ternate sejatinya telah merealisasikan setelah adanya tuntutan tersebut. Bagian yang bertanggung jawab untuk pemasangan meter air adalah Bagian Distribusi PDAM Kota Ternate. Pemasangan meter air secara gratis di Kelurahan Sangaji ini telah selesai dilakukan. Acara peresmian program tersebut dihadiri oleh Direktur Umum PDAM Kota Ternate, Pemerintah Kota Ternate, Pihak Keamanan (Polisi dan TNI), serta warga Kelurahan Sangaji. 


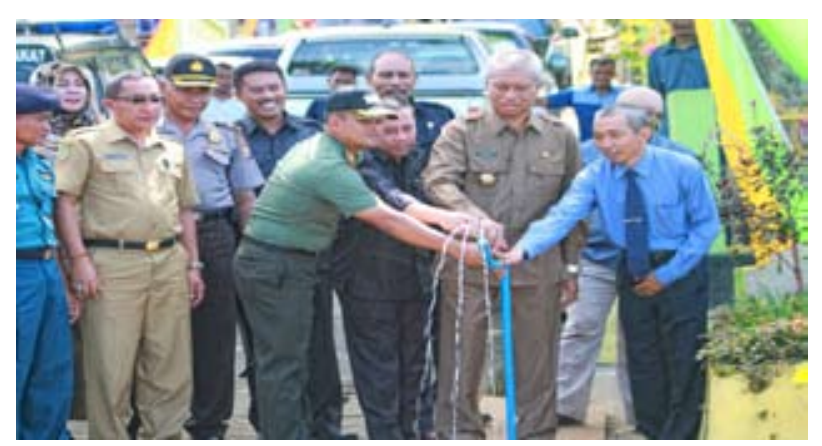

Gambar 2.

Peresmian pemasangan meter air gratis di Kelurahan Sangaji Kecamatan Kota Ternate Utara (PDAM Kota Ternate 2014)

Selain itu, Bagian Distribusi PDAM Kota Ternate juga bertugas merealisasikan program perubahan jaringan air yang disalurkan dari sumber mata air alternatif yang berada di Kecamatan Kota Ternate Selatan. Program perubahan jaringan air dapat dikatakan cukup efektif untuk meredakan komplain warga. Sedangkan kekurangannya, program ini tidak bisa mencakup semua Kelurahan di Kecamatan Kota Ternate Tengah. Berdasarkan hasil wawancara, ditemukan fakta bahwa hanya satu Kelurahan yang permasalahan terkait air asin sudah teratasi dengan adanya perubahan jaringan air yakni Kelurahan Kampung Makassar Barat Kecamatan Kota Ternate Tengah.

Lebih lanjut Bagian Hubungan Langganan PDAM Kota Ternate sendiri dilibatkan dengan tujuan untuk menyampaikan segala sesuatu yang berkaitan dengan permasalahan sumber mata air Ake Gaale. Setiap pelanggan yang datang melakukan komplain akan dijelaskan serinci mungkin agar dapat dipahami letak permasalahannya. Komunikasi yang dilakukan pada dasarnya untuk mengembalikan citra PDAM Kota Ternate.

Berdasarkan hasil wawancara dengan Kepala Seksi Hubungan Langganan PDAM Kota Ternate, dalam penanganan komplain, Hubungan Langganan PDAM Kota Ternate menjelaskan secara transparan terhadap pelanggan terkait masalah sumber mata air Ake Gaale. Penjelasan hanya dilakukan ketika pelanggan datang melakukan komplain di Kantor PDAM Kota Ternate. Komunikasi yang digunakan bagian Hubungan Langganan PDAM Kota Ternate adalah komunikasi interpersonal, yang mana petugas di bagian Hubungan Langganan PDAM Kota Ternate dan pelanggan terlibat dalam komunikasi langsung.

Sedangkan, Humas PDAM Kota Ternate menerapkan komunikasi massa. Dalam menjawab komplain, Humas PDAM Kota Ternate melibatkan Direktur Umum PDAM Kota Ternate untuk membuat pernyataan lewat media cetak lokal. Hasil penelusuran peneliti pada media cetak Malut Post via internet, terdapat artikel Malut Post (6 Desember 2014) yang memuat pernyataan Bapak Syaiful Djafar selaku Direktur Umum PDAM Kota Ternate. Beliau menjelaskan kegiatan produksi air pada sumber mata air Ake Gaale ditingkatkan dengan tujuan untuk memenuhi kebutuhan pelanggan yang telah mencapai angka 23.ooo. Beliau juga menjelaskan bahwa penyebab air asin dikarenakan kemarau panjang yang melanda Kota Ternate yang menyebabkan sumur-sumur PDAM Kota Ternate menjadi kering. Keringnya sumur PDAM Kota Ternate mengakibatkan adanya resapan air laut ke daratan (sumur-sumur PDAM Kota Ternate) sehingga terjadi pencemaran air.

4. Evaluasi

Pada tahap terakhir, Humas PDAM Kota Ternate melakukan evaluasi. Proses evaluasi dititikberatkan pada intensitas komplain yang dilakukan oleh warga. Dari hasil wawancara, maka dapat dijelaskan sebagai berikut:

a. Pengurangan produksi air di sumber mata air Ake Gaale berdampak pada distribusi air yang bergilir. Hal ini tentunya menimbulkan komplain baru oleh warga di Kecamatan Kota Ternate Utara dan Kota Ternate Tengah.

b. Pengurangan produksi air di sumber mata air Ake Gaale ternyata tidak dapat mengembalikan kualitas dan debit air sepenuhnya.

c. Pemasangan air secara gratis di rumah warga Kelurahan Sangaji ternyata tidak menyelesaikan masalah. 
Distribusi air yang dilakukan oleh PDAM Kota Ternate ke rumah warga Kelurahan Sangaji masih terasa asin.

d. Perubahan jaringan air masih dikatakan belum cukup efektif. Hal ini dikarenakan sumber mata air di Kecamatan Kota Ternate Selatan hanya mampu memenuhi kebutuhan pada salah satu Kelurahan di Kecamatan Kota Ternate Tengah.

\section{Penyelesaian Komplain Oleh Humas PDAM Kota Ternate}

Pada dasarnya proses evaluasi yang dilakukan PDAM Kota Ternate menunjukkan bahwa program-program tersebut tidak berjalan dengan efektif. Hal ini dikarenakan program yang dijalankan belum bisa menyelesaikan masalah sehingga intensitas komplain mulai meningkat. Bahkan warga Kelurahan Sangaji bersama mahasiswa Universitas Khairun Ternate pernah melakukan demonstrasi di Kantor PDAM Kota Ternate.
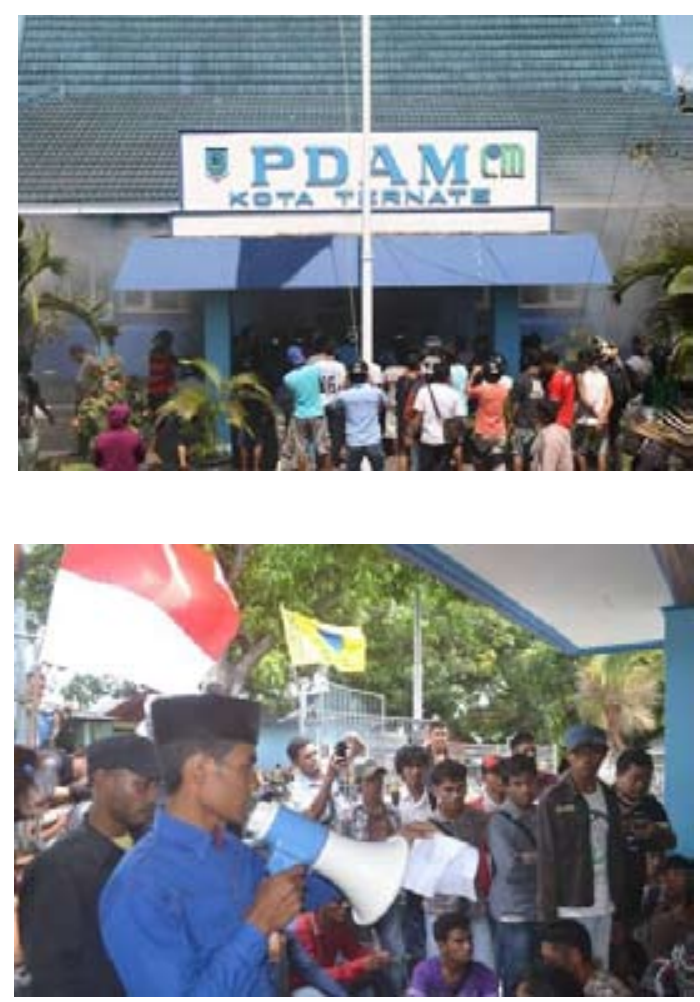

Gambar 3. Warga bersama Mahasiswa Unkhair Ternate Melakukan Demonstrasi di Kantor PDAM Kota Ternate (Dokumentasi oleh Warga diambil pada Tanggal 11

Desember 2014).
Dari reaksi ini, Humas PDAM Kota Ternate mengambil langkah alternatif dengan memberi saran kepada manajemen PDAM Kota Ternate untuk melibatkan Pemerintah Kota Ternate dalam penyelesaian masalah sumber mata air Ake Gaale.
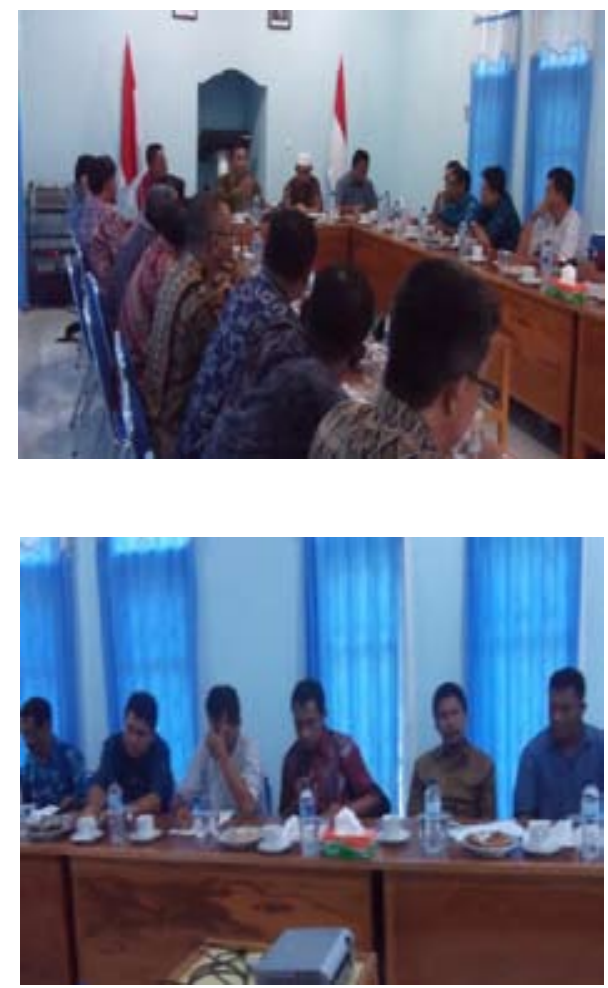

Gambar 4. Rapat mediasi antara Pemerintah Kota Ternate, PDAM Kota Ternate dan Warga Kelurahan Sangaji (PDAMKota Ternate Tahun 2014).

Dari rapat tindak lanjut permasalahan Ake Gaale di atas, semua pihak sepakat pada beberapa rumusan program jangka pendek dan jangka panjang sebagai berikut:

1. Program Jangka Pendek

a. Pengurangan kapasitas produksi pompa yang ada di Ake Gaale;

b. Pengalihan saluran air hujan ke Ake Gaale oleh Dinas PU;

c. Pembangunan sumur resapan pada tahun 2015;

d. Penghijauan (penanaman pohon sagu);

e. Pembuatan tanggul (Bronjong);

f. Fungsikan sumur PDAM lain (sumber alternatif); 
g. Pengawasan berkala pada kesehatan masyarakat; dan

h. Pemeriksaan kualitas air PDAM di masyarakat.

2. Program Jangka Panjang

a. Menerbitkan Peraturan Daerah Perlindungan Air Tanah Kota Ternate;

b. Sosialisasikan Gerakan Cinta Air;

c. Pembangunan Ruang Terbuka Hijau (RTH) di lingkungan Ake Gaale; dan

d. Pengendalian pemukiman (penataan kembali lingkungan Ake Gaale).

\section{Pembahasan}

Dalam upaya untuk menyelesaikan komplain warga, komunikasi interpersonal dianggap paling efektif untuk diterapkan. Hal inidikarenakan maksud dan tujuanyangingin disampaikan oleh warga maupun pegawai di bagian Hubungan Langganan PDAM Kota Ternate dapat diketahui seketika. Hal ini juga berpotensi terjadinya pengembangan komunikasi yang bersifat dialog sehingga informasi yang diterima menjadi luas. Hal ini sejalan dengan pandangan Sunarto (2003: 13) yang menjelaskan bahwa komunikasi interpersonal adalah komunikasi antar komunikator dengan komunikan, komunikasi jenis ini dianggap paling efektif dalam upaya mengubah sikap, pendapat atau perilaku seseorang, karena sifatnya yang dialogis berupa percakapan. Arus balik bersifat langsung, komunikator mengetahui tanggapan komunikan ketika itu juga. Pada saat komunikasi dilancarkan, komunikator mengetahui secara pasti apakah komunikasinya positif atau negatif, berhasil atau tidaknya. Jika ia dapat memberikan kesempatan pada komunikan untuk bertanya seluas-luasnya.

Namun komunikasi massa pun juga penting dilakukan. Baik melalui media cetak maupun elektronik. Media cetak lokal juga penting untuk melakukan komunikasi yang berkesinambungan dan meningkatkan citra baik perusahaan. Rumanti (2005: 118), menjelaskan bahwa secara umum penggunaan media dalam kegiatan Humas mempunyaibeberapatujuanyaitu,membantu mempromosikan dan meningkatkan pemasaran, menjalin komunikasi yang berkesinambungan, meningkatkan kepercayaan publik, dan meningkatkan citra baik organisasi/perusahaan.

Komunikasi massa yang diterapkan Humas PDAM Kota Ternate melalui pernyataan Direktur Umum merupakan suatu bentuk pesan yang mengandung unsur publisitas. Menurut Lesly dalam Iriantara dan Surachman (2008: 190), menjelaskan bahwa publisitas adalah penyebaran pesan yang direncanakan dan dilakukan untuk mencapai tujuan lewat media tertentu oleh dari organisasi dan perorangan tanpa pembayaran tertentu lewat media.

Namun berdasarkan pandangan peneliti, komunikasi massa yang digunakan pihak PDAM Kota Ternate merupakan buntut dari gagalnya komunikasi yang dibangun Humas PDAM Kota Ternate terhadap warga Kelurahan Sangaji. Hal ini dikarenakan adanya perbedaan persepsi terhadap kinerja PDAM Kota Ternate terkait tujuan eksploitasi berlebihan yang dilakukan PDAM Kota Ternate terhadap sumber mata air Ake Gaale. Adanya persepsi berbeda dari warga Kelurahan Sangaji diyakini menjadi faktor penyebab tidak berjalannya komunikasi secara langsung.

Pada dasarnya, perbedaan strategi komunikasi interpersonal dan komunikasi massa ini terletak pada sifatnya. Strategi komunikasi interpersonal bersifat mikro. Sedangkan strategi komunikasi massa bersifat makro. Namun kedua strategi komunikasi ini memiliki tujuan yang sama untuk menyampaikan dan menyebarluaskan informasi terkait permasalahan sumber mata air Ake Gaale. Hal ini sesuai dengan pendapat Effendy (2000: 300), yang menjelaskan bahwa strategi komunikasi, baik secara makro (planned multi-media strategi) maupun secara mikro (single communication medium strategi) mempunyai fungsi untuk menyebarluaskan pesan komunikasi yang bersifat informatif, persuasif dan instruktif secara sistematik kepada sasaran untuk memperoleh hasil optimal. 
Selanjutnya proses evaluasi dilakukan oleh Humas PDAM Kota Ternate. Evaluasi merupakan bagian dari sistem manajemen. Tanpa evaluasi, maka tidak akan diketahui bagaimana kondisi objek evaluasi tersebut dalam rancangan, pelaksanaan serta hasilnya. Cutlip dan Center menjelaskan bahwa proses Humas selalu dimulai dari mengumpulkan fakta dan diakhiri pula dengan pengumpulan fakta. Untuk mengetahui prosesnya sudah selesai atau belum, seorang Humas perlu melakukan evaluasi atas langkah-langkah yang telah diambil. Maka, tahap ini akan melibatkan pengukuran atas hasil tindakan di masa lalu. Penyesuaian dapat dibuat dalam program yang sama, atau setelah suatu masa berakhir.

Humas PDAM Kota Ternate pada saat melakukan evaluasi menemukan fakta bahwa realisasi program jangka pendek yang direncanakan PDAM Kota Ternate tidak berjalan efektif. Dengan adanya hasil evaluasi tersebut, Humas PDAM Kota Ternate menemukan langkah alternatif untuk menyelesaikan komplain warga, khususnya warga Kelurahan Sangaji. Langkah alternatif yang diambil adalah dengan menyarankan Direktur Umum PDAM Kota Ternate untuk melibatkan Pemerintah Kota Ternate dalam penyelesaian masalah sumber mata air Ake Gaale. Langkah alternatif ini diambil karena program-program PDAM Kota Ternate tidak dapat menyelesaikan dampak permasalahan sumber mata air tersebut. Selain itu, tujuan Humas PDAM Kota Ternate melibatkan Pemerintah Kota Ternate adalah untuk menjadi mediator pada proses mediasi terhadap PDAM Kota Ternate dan warga Kelurahan Sangaji yang gagal dalam membangun komunikasi bersama.

As'adi (2012: 4), menjelaskan bahwa mediasi dapat juga digambarkan sebagai suatu sistem dimana mediator mengatur proses dan para pihak mengontrol hasil akhir. Mediasi lebih mudah karena dalam mediasi diupayakan untuk mendapatkan win-win solution antara kedua belah pihak.

Pemerintah Kota Ternatedilibatkan dalam penyelesaian komplain warga dikarenakan PDAM Kota Ternate merupakan Badan
Usaha Milik Daerah (BUMD). Hal ini berarti segala sesuatu yang berhubungan dengan kinerja PDAM Kota Ternate juga merupakan tanggung jawab bersama Pemerintah Kota Ternate. Keterlibatan Pemerintah Kota Ternate pada dasarnya untuk mengarahkan dan memfasilitasi lancarnya komunikasi, serta membantu PDAM Kota Ternate dan warga Kelurahan Sangaji untuk memahami permasalahan yang terjadi.

Lebih lanjut PDAM Kota Ternate dan warga Kelurahan Sangaji juga dapat membuat penilaian yang objektif hingga tercapainya penyelesaian akan masalah yang dihadapi. Pemerintah Kota Ternate sebagai pihak penengah dapat mengajukan sebuah solusi, namun tidak dalam posisi memberikan atau menuntut keharusan kepada pihak PDAM Kota Ternate dan warga Kelurahan Sangaji untuk menjalankan segala kewajiban yang muncul dari solusi tersebut.

\section{SIMPULAN}

Dalam penyelesaian komplain dari warga Kecamatan Kota Ternate Utara dan Kota Ternate Tengah, Humas PDAM Kota Ternate menjalankan peran dan fungsinya sebagai fasilitator komunikasi. Selanjutnya Humas PDAM Kota Ternate menerapkan strategi khusus melalui realisasi programprogram jangka pendek perusahaan dan penggunaan strategi komunikasi. Realisasi program-program jangka pendek PDAM Kota Ternate bermula dari empat proses penting yang meliputi pengumpulan fakta dan mendefinisikan masalah, perencanaan dan program, aksi dan komunikasi, serta evaluasi. Dari keempat proses ini, Humas dan manajemen PDAM Kota Tenate sepakat untuk merealisasikan program-program jangka pendek yang diupayakan untuk menyelesaikan komplain warga. Selain itu, penggunaan strategi komunikasi juga diterapkan Humas PDAM Kota Ternate melalui Hubungan Langganan dan Direktur Umum. Bagian Hubungan Langganan PDAM Kota Ternate menerapakan strategi komunikasi interpersonal yang bersifat mikro. Sedangkan, Direktur Umum PDAM Kota 
Ternate menerapkan startegi komunikasi massa yang bersifat makro.

Pada saat evaluasi, Humas PDAM Kota Ternate menemukan fakta bahwa programprogram yang dijalankan PDAM Kota Ternate tidak efektif. Dengan demikian, Humas PDAM Kota Ternate mengambil langkah alternatif melibatkan Pemerintah Kota Ternate dalam penyelesaian masalah sumber mata air Ake Gaale. Selain itu, keterlibatan Pemerintah Kota Ternate diupayakan untuk dapat menjadi Mediator dalam proses mediasi antara PDAM Kota Ternate dan warga Kelurahan Sangaji sebagai pelaku komplain yang gagal dalam membangun komunikasi bersama. 


\section{DAFTAR PUSTAKA}

\section{Buku}

As'adi, E. 2012. Hukum Acara Perdata Dalam Perspektif Mediasi (ADR) di Indonesia. Yogyakarta: PT. Graha Ilmu.

Cutlip, S.M.,Center,A.H.,\& Broom, G.M. 2006. Effective Public Relations (B.S. Tri Wibowo,Trans. 9 ed.). Jakarta: Kencana Prenadamedia

Effendy, O. 200o. Ilmu Teori dan Filsafat Komunikasi. Bandung: PT. Remaja Rosdakarya.

Effendy, O. 2006. Hubungan Masyarakat:Suatu Studi Komunikasi. Bandung: PT.Remaja Rosdakarya.

Iriantara, Y. dan Surachman, A.Y. 20o8. Edisi Revisi: Public Relations. Bandung : Simbiosa Rekatama Media.

Kasali, R. 200o. Manajemen Public Relations. Jakarta: PT. Temprint.

Kriyantono, Rachmat. 2015. Public Relations, Issue $\mathcal{E}$ Crisis Management. Jakarta: Prenadamedia

Moleong, Lexy J. 2005. Metodologi Penelitian Kualitatif. Bandung: Ramaja Rosdakarya
Rumanti, Sr, MA. 2005. Dasar-Dasar Public Relations : Teori dan Praktik. Jakarta : Grasindo.

Sunarto. 2003. Perilaku Konsumen. Yogyakarta: CV. Ngeksigondo Utama.

\section{Internet}

Malut Post. 2014. "Di Bagian Utara Air PDAM Salobar" http://malutpost. co.id/2014/12/o6/di-bagian-utaraair-pdam-salobar Akses Tanggal o1 Februari 2016

Malut Post. 2015. "Krisis Air Bersih Kian Megancam" http://portal.malutpost. co.id/index.php/pro-public/item/219krisis-air-bersih-kian-mengancam Akses Tanggal 18 April 2016

\section{Sumber Data Lain}

Arsip PDAM Kota Ternate Tahun 2014

Notulen Rapat Tindak Lanjut Permasalahan Ake Gaale Antara Pemerintah Kota Ternate, PDAM Kota Ternate dan Warga Kelurahan Sangaji Pada Tanggal 18 Desember 2014 